\title{
THE EFFECT OF EFFLEURAGE MASSAGE USING VIRGIN COCONUT OIL ON THE RISK LEVEL OF PRESSURE ULCERS IN INTENSIVE CARE UNIT PATIENTS
}

\author{
Rycco Darmareja1, Cecep Eli Kosasih², Ayu Prawesti Priambodo²
}

1. Postgraduate Students in Critical Nursing, Padjadjaran University, Bandung

2. Critical Nursing Lecturer in Postgraduate Study Program, Padjadjaran University, Bandung

\begin{abstract}
Immobilising critically ill patients increases the prevalence of pressure ulcers, which can increase the length of a patient's stay and rehabilitation, whilst leading to increased pain and other complications. An independent intervention of effleurage massage using essential oils is considered to be a preventative measure for integrity anoxia, which causes pressure ulcers. The purpose of this research is to identify the effect of effleurage massage using virgin coconut oil (VCO) on the risk level of pressure ulcers in the intensive care unit. Quasi-experimental one-group pre- and post-tests were performed on 34 patients through purposive sampling, using the Braden Scale. The interventions were carried out for 20 minutes on the back of the head, neck, back, glutei, sacrum, hands and feet. A dependent t-test was used in this research because it met the parametric test requirements, followed by a Repeated Measures ANOVA test. The results of the dependent $t$-test showed that the intervention had a significantly positive effect on pressure ulcers $(p=0.0001)$ if effectively carried out for at least three continuous days. It was concluded that effleurage massage using VCO has a significant effect on reducing the risk level of pressure ulcers in immobilised patients.
\end{abstract}

Keywords: Effleurage massage; Immobilisation; Intensive Care Unit; Pressure ulcers; Virgin Coconut Oil

\section{ABSTRAK}

Imobilisasi pasien kritis berisiko meningkatkan prevalensi pressure ulcers dan berdampak pada peningkatan lama rawat, nyeri, serta komplikasi lain. Intervensi mandiri melalui massage effleurage menggunakan minyak esensial dinilai sebagai pencegahan anoksia integritas yang menyebabkan pressure ulcers. Tujuan penelitian ini adalah untuk mengidentifikasi pengaruh massage effleurage menggunakan VCO terhadap tingkat risiko pressure ulcers pasien tirah baring di ruang intensif. Quasi experimental one group pretest and posttest dilakukan kepada 34 orang melalui purposive sampling dengan instrumen Braden Scale. Intervensi dilakukan selama 20 menit pada area belakang kepala, leher, punggung, gluteal, sakrum, tangan dan kaki. Analisis t-dependen dilanjutkan Repeated Measures ANOVA digunakan karena memenuhi syarat uji parametrik. Hasil uji t-dependen menunjukan terdapat pengaruh massage effleurage menggunakan VCO terhadap pressure ulcers dengan $p=0.0001$, dan efektif dilakukan minimal tiga hari berkelanjutan. Berdasarkan hasil penelitian, disimpulkan massage effleurage menggunakan VCO dinilai berpengaruh terhadap penurunan tingkat risiko pressure ulcers pasien tirah baring.

Kata Kunci: Intensive Care Unit, Immobilisation, Massage effleurage, Pressure ulcers, Virgin Coconut Oil 


\section{INTRODUCTION}

Patients in intensive care are often critically ill and experience physiological, psychosocial, developmental, and spiritual deterioration. Critically ill patients can suffer increased pain, sleep disorders, malnutrition and reduced awareness; and their immobilisation means they are less able to change position and they therefore run the risk of developing pressure ulcers (PU) (Cox, 2011; Kozier et al., 2011).

NPUAP, EPUAP and PPPIA (2014) defined PUs as tissue injuries localised to the skin and/or underneath the tissue (usually above the bone protrusion), as a result of pressure, friction or a combination of both. The condition is caused by a lack of oxygen, nutrients, and accumulation of residual cell metabolism, which ultimately causes cell death. Kayser, VanGilder and Lachenbruch (2019) and Suheri (2009) stated that PUs most often occur three to five days after immobilisation.

The incidence of PUs in intensive care settings varies between hospitals and countries. Cox and Roche (2015) stated that intensive care unit (ICU) patients have a $12-42 \%$ higher risk of PU than other hospitalised patients. Other data show large differences ranging from $8.1 \%$ to 44\% (Becker et al., 2017). Gurusinga (2015) explained that the prevalence of PU in long-term care in the United States in 2012 was relatively high at $15-25 \%$. In Indonesia, by contrast, the prevalence of PUs in intensive care patients reached $33.33 \%$, which was higher than all other countries in ASEAN (Utomo et al., 2012).

This condition has become a serious problem because it causes prolonged pain (due to disruption of the haemodynamic system), increased complications related to sepsis and increased mortality $(2.8 \%$ of sepsis patients die as a result of PUs). It has also led to an increase in rehabilitation programmes, as well as increases in the duration and cost of care (Georgiou et al., 2015; Hyun et al., 2013; Liu et al., 2019; Sole et al., 2013; Tambajong et al., 2016; Urden et al., 2010).

Mizan, Rosa, and Yuniarti (2015) stated that nurses find it difficult to implement measures to prevent PUs. Nurse interventions, based on the recommendations of NPUAP et al. (2014), included risk level assessment, skin and tissue assessment, skincare and mechanical therapy.

The skin is the largest organ in the body. It has many complex functions and is the primary barrier that protects the body from infection. Maintaining the integrity of the skin in critical care situations is often overlooked. In line with the research conducted by Alfianti, Nurhaeni, and Eryando (2012), most critical care nurses focus on the prevention of life-threatening complications. The number of invasive actions and therapies that need to be undertaken was also a reason why skin integrity was neglected.

Some researchers recommended having a massage in order to prevent PUs (Zhang \& Yue, 2015). Massages have been shown to increase circulation to the tissues and maintain skin moisture. This can prevent skin tissue anoxia, which is the main cause of PUs. Handayani, Irawati, and Panjaitan (2011) recommended that effleurage massage be performed for 4-5 minutes every day on bed-rest patients.

A massage requires a suitable essential oil in order for it be carried out effectively so that it can easily work on the body muscles (Widiyanti, 2015). Virgin coconut oil (VCO) is useful for softening the skin and accelerating its healing. VCO has a low water content $(0.02-0.03 \%)$ and a low level of free fatty acids (0.02\%). Additionally, VCO has been shown to have antioxidant, antiviral and antibacterial properties (Widiada et al., 2010).

A literature review has shown that VCO has benefits for skincare and has been shown to prevent PU. However, no studies have been conducted on the efficacy of effleurage massage using VCO on patients in intensive care. This study contributes to the extant research by assessing the PU risk level over a period of five consecutive days. This study also discusses risk factors for PUs such as gender, age, awareness status, blood pressure, muscle strength, Body Mass Index, respiratory support, and blood laboratory indicators. The brief description above provides a basis for conducting 
research aimed at assessing the effect of effleurage massage using VCO on the risk level of PUs in ICU patients.

\section{METHOD}

A quasi-experimental design type was used, and one-group pre- and posttests were conducted on 34 ICU patients in a Type B hospital in Cimahi, West Java, Indonesia. To minimise confounding factors, the researcher selected patients based on the established specified criteria (purposive sampling). The patients had to be more than 45 years, immobilised and have stable haemodynamics (i.e. normal heart rate, MAP, oxygen saturation levels and ECG). The patients should not be malnourished (i.e. normal albumin levels of albumin and no parenteral nutrition therapy) and should have the same daily interventions in the form of mobilisation every two hours whilst using the same anti-PU mattresses and clothing, and the patients should not have had PUs before the interventions.

Data was collected from March 13th to May 29th, 2019, and the study was conducted over a period of five days. Initial assessments were made, and informed consent was obtained on Day 1, the interventions were carried out on Days 2 to 4, and the final interventions and evaluations were carried out on Day 5 . The intervention consisted of 20 minutes of effleurage massage using VCO following the protocol created for the study. Effleurage massage is performed on the mastoid bone area, back of the neck, back, glutei, sacrum, hands, and feet. Interventions were carried out twice a day after washing, and then further periodic observations were made.

Primary data was collected using the Braden Scale for Predicting Pressure Score Risk and through general
information
and
observations questionnaire.

Researchers obtained permission to use the Braden Scale from the developer. The Braden Scale consists of six indicators: sensory perception, moisture, activity, mobility, nutritional status and friction, and tears. The Braden Scale has a total value of 23 , with a score of $>18$ indicating the patient is not at risk of PUs, 15-18 indicates low risk, 13-14 indicates medium risk, 10-12 indicates high risk, and less than 10 indicates very high risk (Santos et al., 2018).

Mufarika (2012) stated that the Braden Scale has good validity at cut-off point 11 , a sensitivity of $80 \%$, a specificity of $93.3 \%$, a positive predicting value of $92.3 \%$, a negative predicting value of $82.4 \%$, a false positive of 12.0 , a false negative of 0.2 and an area under the receiver-operating characteristic of 0.898 . Mizan et al. (2015) added reliability coefficients of $0.878(\geq 0.6)$. Based on previous studies, the Braden Scale is valid and dependable.

Univariate analysis was carried out to obtain the frequency distribution and presentation of each variable. For bivariate analysis, the level of risk of PUs was determined by a dependent t-test, before being followed by a Repeated Measure ANOVA test and a post hoc Bonferroni test to assess the effectiveness of the intervention against the level of risk of PUs.

The study considered the ethical principles of autonomy, informed consent, beneficence, non-maleficence, justice, privacy and anonymity, and confidentiality. Ethical approval for this study was given by the Health Research Ethics Commission, Faculty of Medicine at the University of Padjadjaran, study no. 256/UN6.KEP/EC/2019.

\section{RESULT}

Participants' Characteristics

A list of the participants' characteristics is presented in Table 1.

Table 1. Distribution of the participants' characteristics, $n=34$

\begin{tabular}{lcc}
\hline Characteristics of participants & Frequency $(f)$ & Percentage $(\%)$ \\
\hline Gender & & \\
Male & 16 & 47.1 \\
Female & 18 & 52.9 \\
\hline
\end{tabular}




\begin{tabular}{|c|c|c|}
\hline Characteristics of participants & Frequency $(f)$ & Percentage (\%) \\
\hline \multicolumn{3}{|l|}{ Age } \\
\hline Middle aged ( $45-49$ years) & 12 & 35.3 \\
\hline Elderly $(60-74$ years) & 14 & 41.2 \\
\hline Older people (75-89 years) & 7 & 20.6 \\
\hline Very old age (>90 years) & 1 & 2.9 \\
\hline \multicolumn{3}{|l|}{ GCS/Awareness level } \\
\hline Compos mentis (GCS 15) & 3 & 8.8 \\
\hline Somnolent (GCS 12-14) & 4 & 11.8 \\
\hline Stupor (GCS 9-11) & 9 & 26.5 \\
\hline Coma (GCS 3-8) & 18 & 52.9 \\
\hline \multicolumn{3}{|l|}{ Blood pressure } \\
\hline Normal $(<120 /<80 \mathrm{mmHg})$, & 11 & 32.4 \\
\hline Elevated $(120-129 /<80 \mathrm{mmHg})$ & 9 & 26.5 \\
\hline Hypertensive $(\geq 130 / 80 \mathrm{mmHg})$ & 14 & 41.2 \\
\hline \multicolumn{3}{|l|}{ Participants' muscle strength } \\
\hline Scale $0(0 \%)$ & 4 & 11.8 \\
\hline Scale $1(10 \%)$ & 12 & 35.3 \\
\hline Scale $2(25 \%)$ & 10 & 29.4 \\
\hline Scale $3(50 \%)$ & 5 & 14.7 \\
\hline Scale $4(75 \%)$ & 3 & 8.8 \\
\hline \multicolumn{3}{|l|}{ Body Mass Index category } \\
\hline Únderweight & 1 & 2.9 \\
\hline Normal & 13 & 38.2 \\
\hline Overweight & 9 & 26.5 \\
\hline Obesity I & 8 & 23.5 \\
\hline Obesity II & 3 & 8.8 \\
\hline \multicolumn{3}{|l|}{ Respiratory status support } \\
\hline Ventilator Machine & 14 & 41.2 \\
\hline Non-Rebreathing Mask & 13 & 38.2 \\
\hline Simple Mask & 1 & 2.9 \\
\hline Binasal Cannula & 6 & 17.6 \\
\hline \multicolumn{3}{|l|}{ Haemoglobin levels } \\
\hline Value $<7$ & 1 & 2.9 \\
\hline Value $7-13\left({ }^{\lambda}\right)$ and $7-11($ ( $)$ & 18 & 52.9 \\
\hline Value $14-18\left({ }^{\prime}\right)$ and $12-16$ (ㅇ) & 15 & 44.1 \\
\hline \multicolumn{3}{|l|}{ Haematocrit levels } \\
\hline 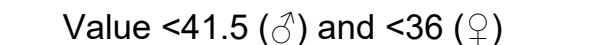 & 21 & 61.8 \\
\hline Value 41.5-50.4 ( $\left.{ }^{\top}\right)$ and 36-45 (+) & 12 & 35.3 \\
\hline Value $>50.4\left({ }^{\lambda}\right)$ and $>45($ ( $)$ & 1 & 2.9 \\
\hline \multicolumn{3}{|l|}{ Leukocyte levels } \\
\hline Value $<4.5$ & 3 & 8.8 \\
\hline Value $4.5-11.0$ & 10 & 29.4 \\
\hline Value $>11.0$ & 21 & 61.8 \\
\hline \multicolumn{3}{|l|}{ Grade pressure ulcers } \\
\hline Pre-test: No pressure ulcers & 34 & 100 \\
\hline Post-test: No pressure ulcers & 34 & 100 \\
\hline
\end{tabular}

Table 1 shows that from the 34 participants, more than half $(52.9 \%)$ were female, with almost half (41.2\%) aged between 60 and 74. Additionally, almost half the participants suffered from hypertension and had to use a ventilator $(41.2 \%)$, almost all (91.2\%) had decreased muscle awareness and strength. More than half the patients were overweight or obese (58.8\%), had decreased haemoglobin $(55.8 \%)$ and haematocrit levels $(61.8 \%)$, and increased leukocyte levels $(61.8 \%)$. The results found that none of the participants suffered from PUs either before or after the intervention. 
Risk Level of Pressure ulcers

Table 2. Distribution of the risk level of PUs before and after the interventions

\begin{tabular}{lcccc}
\hline Risk level & \multicolumn{2}{c}{ Pre-test } & \multicolumn{2}{c}{ Post-test } \\
\cline { 2 - 5 } $\begin{array}{l}\text { of pressure } \\
\text { ulcers }\end{array}$ & $\boldsymbol{f}$ & $\%$ & $\boldsymbol{f}$ & $\%$ \\
\hline Not at risk (>18) & 0 & 0 & 2 & 5.9 \\
Low risk (15-18) & 2 & 5.9 & 5 & 14.7 \\
Moderate risk & 4 & 11.8 & 8 & 23.5 \\
(13-14) & 13 & 38.2 & 13 & 38.2 \\
High risk (10-12) & 15 & 44.1 & 6 & 17.6 \\
\hline Very high risk $(<9)$ & 15
\end{tabular}

Table 2 shows that of the 34 patients in the ICU, slightly less than half $(44.1 \%)$ were at very high risk of PUs before the interventions, while the number shrank to less than a quarter (17.6\%) at very high risk after the interventions. Based on this, we identified a change in the frequency distribution of the risk levels of PUs in patients after the interventions.

Table 3. Distribution of changes in the risk level category of the ICU patients' PUs both before and after the interventions

\begin{tabular}{lcc}
\hline Category change & $\boldsymbol{f}$ & $\%$ \\
\hline Risk level & 4 & 11.8 \\
deterioration & 8 & 23.5 \\
$\begin{array}{l}\text { Fixed risk level } \\
\text { Risk level }\end{array}$ & 22 & 64.7 \\
improvement & & \\
\hline
\end{tabular}

Table 3 shows that more than half of the respondents (64.7\%) experienced an improvement in their risk level, meaning that either their Braden Scale scores increased or the risk level category for PUs decreased after intervention.

\section{Effect of Effleurage Massage on the Risk Level of Pressure Ulcers}

A dependent t-test was used to identify the effects of the interventions on the risk of PUs, followed by an analysis of the effectiveness of the effect pattern. The results can be seen in Table 4 and 5.

Table 4. Differences in the mean risk levels of PUs both before and after the intervention

\begin{tabular}{|c|c|c|c|c|c|c|}
\hline \multirow{2}{*}{ Risk level score } & \multirow{2}{*}{ Mean } & \multirow{2}{*}{ SD } & \multicolumn{2}{|r|}{ Paired } & \multirow{2}{*}{$\mathbf{T}$} & \multirow{2}{*}{$P$} \\
\hline & & & $\triangle$ Mean & $95 \% \mathrm{Cl}$ & & \\
\hline $\begin{array}{l}\text { Pre-test } \\
\text { Post-test }\end{array}$ & $\begin{array}{l}10.29 \\
12.41\end{array}$ & $\begin{array}{l}2.444 \\
3.036\end{array}$ & -2.118 & $(-3.148 \mathrm{~s} / \mathrm{d}-1.088)$ & -4.183 & $0.0001^{*}$ \\
\hline
\end{tabular}

Dependent t-test

The average risk level of the respondents' PUs before intervention was 10.29, whereas after intervention the average risk level was 12.41, which means that the risk level decreased by an average of 2.118 . The results of the dependent t-test at a significance level of 95\% with alpha (a) 0.05 were obtained with a $p$-value of 0.0001 . This means that effleurage massage has a significant effect on the risk level of PUs in ICU patients.

Table 5. Post hoc test results of the risk level of PUs over time

\begin{tabular}{|c|c|c|c|c|c|}
\hline $\begin{array}{l}\text { Comparison } \\
\text { measures }\end{array}$ & of periodic & intervention & $\begin{array}{l}\text { Mean } \\
\text { difference }\end{array}$ & $p^{*}$ & $95 \% \mathrm{Cl}$ \\
\hline \multirow[t]{4}{*}{ Initial } & Day 1 & & 0.147 & 1.000 & $-0.490--0.784$ \\
\hline & Day 2 & & -0.882 & 0.108 & $-1.864-0.100$ \\
\hline & Day 3 & & -2.147 & 0.000 & $-3.516-0.778$ \\
\hline & End & & -2.118 & 0.002 & $-3.640-0.595$ \\
\hline \multirow[t]{3}{*}{ Day 1} & Day 2 & & -1.029 & 0.003 & $-1.786--0.273$ \\
\hline & Day 3 & & -2.294 & 0.000 & $-3.555--1.003$ \\
\hline & End & & -2.265 & 0.000 & $-3.703--0.826$ \\
\hline \multirow[t]{2}{*}{ Day 2} & Day 3 & & -1.265 & 0.002 & $-2.174--.0 .355$ \\
\hline & End & & -1.235 & 0.012 & $-2.283--0.188$ \\
\hline Day 3 & End & & 0.029 & 1.000 & $-0.294-0.353$ \\
\hline
\end{tabular}

The results of the post hoc (Bonferroni) test in Table 5 show that effleurage massage produces a pattern of significant differences over time, as evidenced by the results of significance time by time $<0.05$. However, if the initial 
examination was compared with the data after the third day of intervention, the final examination would show a difference in the average of -2.147 and -2.118 , which is significant $(p=0.000$ and $p=0.002)$. This shows that effleurage massage is effective if it is performed on at least three consecutive days.

\section{DISCUSSION}

The results of the analysis show that the 34 immobilised patients in the ICU who had had effleurage massage interventions showed either an increase in their Braden Scale scores or a decrease in their PU risk levels after the interventions.

The risk factors that are thought to increase the prevalence of $\mathrm{PU}$ include immobilisation, inadequate nutrition, incontinence, ageing, decreased mental status and sensation, and disease. An increased risk of PU was also affected by patient dependence. Patients with higher dependence (full-time care) would have a higher risk than those with lower levels of dependence (Garcia-Fernandez et al., 2014; Kozier et al., 2011).

A study by Okatiranti, Ria, and Dini (2013) showed that $45.95 \%$ of patients needing part-time care were at risk of $\mathrm{PU}$, while $44.12 \%$ of those needing full-time care were at high risk. Retrospective analysis of a study by Medeiros et al. (2018) with 180 respondents showed that risk factors for developing PUs in ICU patients include friction $(\mathrm{OR}=5.97)$, a history of previous PUs (OR=5.43), long periods in the ICU $(\mathrm{OR}=3.92)$, dehydration $(\mathrm{OR}=3.18)$, increased temperature $(\mathrm{OR}=3.12)$ and other comorbid treatments $(\mathrm{OR}=2.97)$.

Underweight patients, according to their Body Mass Index (BMI), are three times more likely to develop a PU because having less fat means that pressure is increased on the bones. However, the risk of developing PUs in patients with excess $\mathrm{BMI}$ is eleven times greater due to excessive sweating that can accumulate in the skin folds (Hyun et al., 2014; Ness et al., 2017).

Reviewing the impact of $\mathrm{PU}$ is a complex procedure, so prevention is a priority for nurses. Sihombing, Yuniarlina, and Supardi (2016) mentioned that almost
$95 \%$ of PUs can be prevented through good nursing practices including skin care, mechanical prevention, and surface support, as well as educating patients and their families.

The researchers' hypothesis stated that effleurage massage has a significant effect on the risk levels of PUs in immobilised patients in the ICU, with a pvalue of 0.0001 . This is in line with research conducted by Widodo et al. (2017) who obtained a p-value of 0.000 $(<0.05)$, showing that there was a significant difference in the risk score for PUs before and after a combination of positioning, massage and health education. The hypothesis is also supported by a study conducted by Andani et al. (2016) who showed that there was a significant difference in the risk levels for PUs between patients who had had a bed massage and those that did not, with a $p$ value of 0.031 .

A whole-body massage is a safe and effective treatment that can be given to ICU patients in order to reduce physical and psychological problems (Hetefi et al., 2015). One of the most common sideeffects of the critical care environment is haemodynamic instability, which can be managed through a variety of complementary therapies, including massage therapy (Jamaati et al., 2015).

A massage is beneficial because it increases oxygen flow in the blood, facilitating the removal of metabolic waste, and it increases wellbeing due to the increase in endorphin production, as well as making the skin more radiant and textured (Shinde \& Anjum, 2014; Westman \& Blaisdell, 2016). A study by Setiani (2014) found that effleurage massage can increase levels of comfort and wellbeing and can minimise the occurrence of infections and PUs.

A lubricating agent should always be used during a massage in order to prevent injuries to the skin due to friction (Institute For Health Care Improvement, 2011). Handayani (2010) explained that using moisturisers when massaging dry skin is important in order to restore the skin's natural moisture. Lechner et al. (2017) added that dry skin causes damage to the barrier function, decreasing skin 
elasticity. It is important, therefore, to keep the skin moist by using either lotion or oil when massaging.

Essential oils are beneficial as they protect the skin against pressure and friction, provide optimal hydration, and prevent the build-up of oxygen-deficient cells (Leir, 2010). VCO is believed to improve skin health as it is easily absorbed and protects the skin from excessive evaporation. The results of a study by Sihombing et al. (2016) showed that a back massage using VCO can reduce the risk of PUs by $80 \%$ in patients who are at significant risk, with a $p$-value of 0.025 . A comparative test with white petroleum jelly can only reduce the risk by $68 \%$.

VCO has a significant moisturising component, which can soften the skin and protect it from damage. In addition, it contains antioxidants as well as antimicrobial and anti-fungal agents that can protect the skin against free radicals and tissue degeneration.

VCO is easily absorbed by the skin, contains vitamin $\mathrm{E}$, and has a $\mathrm{pH}$ which is close to a commercial skin moisturiser, so it is also safe to use as a moisturiser (Kasor, 2015; Widiyanti, 2015).

Vitamin $E$ can function as a cell membrane stabiliser and can protect skin cells from damage by free radicals and fat deposits in the organelles (Fatonah et al., 2013). This is supported by Sari (2018) who states that using VCO as a moisturiser can help skin stay young and healthy.

Intensive monitoring in hospitals needs to be undertaken to assess which patients are at risk of PUs. In this way, nurses will be able to determine the most appropriate preventative measures. Monitoring of patients is an effective way of determining whether patients are at greater or lesser risk of developing PUs.

A Repeated Measure ANOVA test gave a p-value of 0.000 , which means there are significant differences between each average risk level check over time. Referring to the results of the post hoc Bonferroni test, effleurage massage produces a significant difference the risk level of PUs over time. However, if the results obtained were compared from the initial assessment until the end of the intervention, the implementation of the effleurage massage intervention was considered effective if it was performed over at least three consecutive days.

The implications for nursing, based on the results of this study, are that effleurage massage intervention using VCO is effective in reducing the prevalence of PUs in ICU patients by reducing the risk level. However, this study has also shown that a massage must be performed comprehensively and continuously.

Comprehensive implementation means that the massage interventions should be performed based on the results of a physical assessment, and should focus on skin integrity, nutritional status with regard to BMI, the patient's degree of mobilisation, and their body surface area. The results of the study can then be used in the implementation of effleurage massage using VCO, which has been shown to effectively keep the skin moist under normal conditions (soft, smooth, and elastic), with a massage being given to patients for 20 minutes, depending on their body surface area. Assessing other supporting data, such as the APACHE score and other laboratory data, and noting recommendations for replacing bed linen by the moisture indicator on the Braden Scale cannot currently be undertaken at this point, due to lack of access to a laboratory and the hospital's practice of only changing bed linen once a day.

\section{CONCLUSION}

This study has shown that effleurage massage using VCO has a significant effect on reducing the risk level of developing PUs on immobilised patients in the ICU. The researchers recommend an independent complementary nursing intervention of 20 minutes of effleurage massage using VCO after bathing the patient. This is based on a comprehensive assessment of Braden Scales and can be used as institutional standard policies based on evidence-based practice for preventing PUs on bed-rest patients in the ICU. 


\section{REFERENCES}

Alfianti, D., Nurhaeni, N., \& Eryando, T. (2012). Pengaruh perawatan kulit berdsarkan skor braden $Q$ terhadap kejadian luka tekan anak di PICU RS. Tugureji dan Roemani Semarang. UNIMUS.

Andani, M. F., Kristiyawati, S. P., \& Purnomo, E. C. (2016). Efektivitas alih baring dengan massage punggung terhadap risiko dekubitus pasien tirah baring di RSUD Ambarawa. Jurnal IImu Keperawatan Dan Kebidanan.

Becker, D., Tozo, T. C., Batista, S. S., Mattos, A. L., Silva, M. C. B., Rigon, S., Laynes, R. L., Salomão, E. C., Hubner, K. D. G., Sorbara, S. G. B., \& Duarte, P. A. D. (2017). Pressure ulcers in ICU Patients: incidence and clinical and epidemiological features: A multicenter Study in Southern Brazil. Intensive and Critical Care Nursingal Care, 42, 55-61. https://doi.org/10.1016/j.iccn.2017.03 .009

Cox, J. (2011). Predictors of Pressure Ulcer in Adult Critical care Patients. American Journal Of Critical Care, 20(5), 364-376. https://doi.org/http:// dx.doi.org/10.1590/S0080-62342011 000200002

Cox, J., \& Roche, S. (2015). Vasopressors and development of pressure ulcers in adult critical care patient. American Journal Of Critical Care, 24(6), 501-510. https://doi.org/10.40 37/ajcc2015123

Fatonah, S., Kartika, A., \& Dewi, R. (2013). Efektivitas penggunaan VCO secara Topikal Untuk Mengatasi Luka Tekan Grade I dan II. Jurnal Kesehatan, IV(1), 264-270.

Garcia-Fernandez, F. P., Agreda, J. J. S., Verdo, J., \& Pancorbo-Hidalgo, P. L. (2014). A new theoretical model for development of pressure ulcers and other dependence related lesions. Journal Nursing Scholarship, 46(1),
28-38. https://doi.org/10.1111/jnu.12 051

Georgiou, E., Hadjibalassi, M., Lambrinou, E., Andreou, P., \& Papathanasso glou, E. D. E. (2015). The Impact of Pain Assessment on Critically III Patients' Outcomes: A Systematic Review. Biomed Research International, 1-18. https://doi.org/ $10.1155 / 2015 / 503830$

Gurusinga, R. (2015). Pengaruh Pemberian Posisi Miring Kanan dan Kiri Terhadap Pencegahan Luka Dekubitus Klien Stroke di RSUD Deli Serdang Lubuk Pakam. Jurnal IImiah Kemastra, 4(3), 91-106.

Handayani, R. S. (2010). Efektivitas penggunaan VCO dengan teknik massage untuk pencegahan luka tekan Grade I pada pasien yang beresiko luka tekan di RSUD DR. Hj. Abdoel Moeloek Provinsi Lampung. Universitas Indonesia.

Handayani, R. S., Irawati, D., \& Panjaitan, R. U. (2011). Pencegahan Luka Tekan Melalui Pijat Menggunakan VCO. Jurnal Keperawatan Indonesia, 14(3), 141-148.

Hetefi, M., Jaafarpour, M., Khani, A., Khajibikhan, J., \& Kokhazade, T. (2015). The Effect of Whole Body Massage on the Process and Physiological Outcome of Trauma ICU Patients. Journal of Clinical and Diagnostic Research, 9(6), 5-8. https://doi.org/10.7860/JCDR/2015/1 2756.6096

Hyun, S., Li, X., Vermillion, B., Newton, C., Fall, M., Kaewprag, P., MoffattBruce, S., \& Lenz, E. R. (2014). Body mass index and pressure ulcer: improved predictability of pressure ulcers in Intensive care patients. American Journal of Critical Care, 23(6), 494-501. https://doi.org/ 10.4037/ajcc2014535

Hyun, S., Vermilion, B., Newton, C., Fall, M., Li, X., Kaewprag, P., MoffattBruce, S., \& Lenz, E. R. (2013). 
Predictive Validity of The Braden Scale For Patients in Intensive Care Unit. American Association of Critical Care Nurses, 22(6), 514-520. https://doi.org/10.4037/ajcc2013991

Institute For Health Care Improvement. (2011). How to Guide: Prevent Pressure Ulcer. Institute For Health Care Improvement Cambridge.

Jamaati, H., Vahedian-Azimi, A., Ebadi, A., Ahmadi, F., Saadat, S., Kashafi, M. B., Asghari-Jafarabadi, M., Avezeh, A., \& Hasehemian, S. (2015). Therapeutic effect of massage on the patients in Intensive Care Unit. Critical Care Medicine, 1(1), 1-8. https://doi.org/10.5812/ac cm.519

Kasor, F. (2015). Pengaruh Penggunaan VCO sebagai emolien terhadap sifat fisik dan stabilitas Viamin $C$ dalam sabun transparan. Universitas Muhammadyah Surakarta.

Kayser, S. A., VanGilder, C. A., \& Lachenbruch, C. (2019). Predictors of superficial and severe hospitalacquired pressure injuries: A crosssectional study using the International Pressure Ulcer Prevalence survey. International Journal Of Nursing Studies, 89, 4652. https://doi.org/10.1016/j.jinurstu. 2018.09.003

Kozier, B., Erb, G., Berman, A., \& Snyder, S. J. (2011). Buku ajar fundamental keperawatan: Konsep, Proses dan praktik (7th ed.). EGC.

Lechner, A., Lahmann, N., Neumann, K., Blume-Petavi, U., \& Kottner, J. (2017). Dry skin and pressure ulcer risk: A multi-center cross-sectional prevalence study in German hospitals and nursing homes. International Journal of Nursing Studies, 73, 63-69. https://doi.org/ 10.1016/j.jinurstu.2017.05.011

Leir, E. D. (2010). Pressure Ulcer for nursing assistants and family caregiver. http://stoppain.org
Liu, Y., Wu, X., Ma, Y., Li, Z., Cao, J., Jao, J., Liu, G., Li, F., Song, B., Jin, J., Liu, Y., Wen, X., Cheng, S., \& Lin, F. (2019). The prevalence, incidence, and associated factors of pressure injuries among immobile inpatients: A multicenter, cross sectional, exploratory descriptive study in China. International Wound Journal, 1-8. https://doi.org/10.1111/iwj.130 54

Medeiros, A. B. de A., Fernandes, M. I. da C. D., Tinôco, J. D. de S., Cossi, M. S., Lopes, M. V. de O., \& Lira, A. L. B. de C. (2018). Predictors of pressure ulcer risk in adult intensive care patients: A retrospective casecontrol study. Intensive And Critical Care Nursing, 45, 6-10.

Mizan, D. M., Rosa, E. M., \& Yuniarti, F. A. (2015). Perbandingan Skala Branden dan Skala Gosnell dalam Menilai Tingkat Resiko Luka Tekan. Prosiding Interdisciplinary Postgraduate Student Conference 1st, 259-263.

Mufarika. (2012). Validitas Skala Braden dan Suriadi Sanada dalam menentukan resiko kejadian luka tekan pasien kritis di NCCU RSUP. Dr. Hasan Sadikin Bandung. Universitas Padjadjaran.

Ness, S. J., Hickling, D. F., Bell, J. J., \& Collins, P. F. (2017). The pressures of obesity: the relationship between obesity, malnutrition and pressure injuries in hospital inpatients. Clinical Nutrition, 37(5), 1569-1574. https:// doi.org/10.1016/j.clnu.2017.08.014

NPUAP, EPUAP, \& PAN PACIVIC. (2014). Prevention and treatment of pressure ulcer: Quick reference guide. Cambridge Media.

Okatiranti, Ria, E., \& Dini, T. (2013). Gambaran resiko terjadinya dekubitus berdasarkan tingkat ketergantungan pasien di ruang perawatan neurologi. Jurnal 
Keperawatan Padjajaran, 1(3), 4349.

Santos, V. L. C. de G., Serpa, L. F., Cordero, G. M. L., Gamboa, S. G., Campos, H. H., \& Castañeda, O. C. (2018). Risk Assessment In Pressure Ulcers. Science and Practice of Pressure Ulcer Management, 55-77. https://doi.org/ 10.1007/978-1-4471-7413-4_5

Sari, E. D. (2018). Pengaruh pemberian virgin coconut oil pada area tertekan untuk mencegah luka tertekan pada pasien tirah baring. Universitas Tanjungpura Pontianak.

Setiani, D. (2014). Efektivitas Massage dengan Virgin Coconut Oil terhadap Pencegahan Luka Tekan di Intensive Care Unit. Jurnal Husada Mahakam, III(8), 384-442.

Shinde, M. B., \& Anjum, S. (2014). Effectiveness of slow back massage on Quality of Sleep among ICU patient's. International Journal of Science and Research, 3(3), 292298.

Sihombing, E. R., Yuniarlina, R., \& Supardi, S. (2016). The Effectiveness of back massage using virgin coconut oil and white petroleum jelly to prevent pressure sores. Jurnal Keperawatan Muhammadiah, 1(2), 1-9.

Sole, M. L., Klein, D. ., \& Moseley, M. J. (2013). Introduction to critical care nursing (6th ed.). Elsevier.

Suheri, S. (2009). Gambaran lama hari rawat dalam terjadinya luka dekubitus pada pasien immobilisasi di RSUP Haji Adam Malik Medan. Universitas Sumatera Utara.

Tambajong, R. N., Lalenoh, D. C., \& Kumaat, L. (2016). profil penderita sepsis di ICU RSUP Prof. Dr. R.D. Kandou Manado Periode Desember 2014 - November 2015. Jurnal ECilnic, 4(1), 452-457.

Urden, L. D., Stacy, K. M., \& Lough, M. . (2010). Critical care nursing: Diagnosis and management. Mosby Elsevier.

Utomo, W., Dewi, Y. I., \& Abdurrasyid, T. (2012). Efektivitas Nigella Sativa Oil untuk mencegah terjadinya ulkus dekubitus pada klien tirah baring lama. Jurnal Ners Indonesia, 2(2), 151-157.

Westman, K. F., \& Blaisdell, C. (2016). Many Benefits, Little Risk: The use of massage in nursing practice. American Journal Nursing, 116(1), 34-39.

Widiada, I. G. ., Suhaema, S., \& Gunarti, G. (2010). Perbandingan komposisi asam lemak VCO hasil Fermentasi Starter Ragi Roti dengan VCO hasil pabrikan serta aktivitas antibakterinya pada bakteri penyebab diare. https://poltekkesmataram-ac.id.

Widiyanti, R. A. (2015). Pemanfaatan kelapa menjadi VCO sebagai antibiotik kesehatan dalam upaya mendukung Visi Indonesia Sehat 2015. Prosiding Seminar Nasional Pendidikan Biologi, 577-584.

Widodo, W., Rosa, E. M., \& Kurniasari, N. (2017). Pengaruh Tindakan Keperawatan Reduksi Luka Tekan Terhadap penurunan Risiko Luka Tekan di RSU PKU Muhammadyah Purworejo. Universitas Muhammadyah Yogyakarta.

Zhang, S. Z., \& Yue, J. (2015). Massage Therapy for preventing pressure ulcer. The Cochrane Collaboration: John Wiley \& son Ltd. 